\title{
OCCURRENCE OF ELEPHANTIASIS IN NANDURBAR DISTRICT, OF (M.S), INDIA
}

\author{
Ahirraon Indrarao Shaligram ${ }^{*} 1$ 不 \\ ${ }^{* 1}$ P.G. Departmen of Zoology, S. S. V. P. S’s L. K. Dr. P. R. Ghogrey Science College, Dhule (M. S), India
}

DOI: https://doi.org/10.29121/ijetmr.v7.i9.2020.790

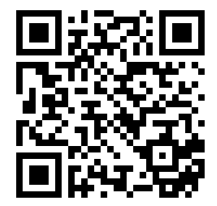

Article Citation: Ahirraon Indrarao Shaligram. (2020). OCCURRENCE OF ELEPHANTIASIS IN NANDURBAR DISTRICT, OF (M.S), INDIA. International Journal of Engineering Technologies and Management Research, 7(9), 80-84. https://doi.org/10.29121/ijetmr.v7 ii 9.2020 .790

Published Date: 30 September 2020

Keywords:

Elephantiasis

Wuchereria-bancrofti

Culex pipiens

C. fatigans

C. quinquifiatus

Nandurbar

\begin{abstract}
Elephantiasis is caused by parasite Wuchereria bancrofti transmitted through the bites of Culex pipiens, C. quinquefaciatus, C. fatigans, B.malayi, Aedes niveus in Andaman and Nicobar islands.mosquitoes. Diseased organisms body transmits the Wuchereria bancrofti to healthy person. Elephantiasis is also known as Filariasis.
\end{abstract}

\section{INTRODUCTION}

As the elephantiasis is like a leg of elephant appearance. Hence is called elephantiasis and as it is caused by Wuchereria is also known as Wuchereriasis disease. It is very prevalent in Navapur Tahsil as climate of this area is very favourable for the development of Culex pipiens, C. quinquefaciatus,_species. Such outbreak of Filariasis was also recorded bye in Navapur tahsil near Chinchapada village, is SAVRAT, BK and Savrat Khurd, under P. H. C. Dr. Vasave was working in Chinchapada village (2004-2005). And Prakasha P. H. C. also reported the patients during the same year of Shahada Tahsil. As the people are also illiterate in this tribal area. Rice-fields as well as rain is more, improperdrainage system or poor-sanitation, living in houses made traditionally, they do not take part in discussion with people of other place, they fear to other people besides Maharashtra District cases were also reported from other states of India

In Maharashtra, there are 17 districts of Filariasis worm disease like, Akola, Amravati, Bhandara, Chandrapur, Gadchiroli, Gondia, Jalgaon, Latur, Nagpur, Nanded, Nandurbar, Osmanabad, Shindhudurg,, Solapur, Thane, Wardha, and Yavatmal. (2017) 40,204, cases of Lymphedema, Thane-Palghar 971cases, Gadchiroli 4669 cases reported from Dr. Shashikant Jadhav, Joint- Director, Malaria and Filaria (M.S.), India. Outbreak of Filariasis also occur in the Andhrapradesh, in East Godavari district, during May, 25, (2020), in last month. A tropical parasitic disease that affected lymph nodes and lymph vessels. Lymphatic Filariasis. More than

(C) 2020 The Author(s). This is an open access article distributed under the terms of the Creative Commons Attribution License, which permits unrestricted use, distribution, and reproduction in any medium, provided the original author and source are credited. 
Occurrence of Elephantiasis in Nandurbar District, of (M.S), India

5000 cases are recorded in India. Government Agencies record, shows, over 120 million people across the Globe, Mostly in Tropics of Asia, Western Pacific, Africa, Parts of Carribean and South America.

Those in the US who have the disease, which is spread by mosquitoes that carry baby worms, / infected while travelling abroad. This leads to dysfunction of the lymph system causing swelling in the limbs known as Lymphedema. Hardening of the arms and legs is called as Elephantiasis. Swelling of scrotum in men is called as Hydrocele.

Lymphatic Filariasis is leading cause of permanent disability worldwide as reported by the survey by the Centers for Disease Control and Prevention.

Filariasis is caused by infection with round worm. Wuchereria-bancrofti, through the bite of infected blood sucking black- flies and mosquito Culex pipiens. ,C.quinquefaciatus.species., C. fatigans.

B. malayi is transmitted by Mansonia mosquitoes and is restricted to South and South East Asia. It is one of the tropical disease targeted for the elimination by the year 2020 declared by WHO. Human filarial nematode worm have the complicated life cycle, which primarily consists of 5-stages. After the male and female worms mate, the female gives birth to live Microfilariae by the thousands. The Microfilariae are taken by the vector insect called as INTERMEDIATE Host during a blood meals, the insect vector such, Culex pipiens species injects the infectious larvae into the dermis layer of skin. After about one year, the larvae molt through the moulting stages, maturing into adult worms Mansonia perstans.

C. quinquefaciatus has been the most predominantly contribute $99.4 \%$ infection in India. Aedes niveus is causing lymphatic Filariasis in Andaman and Nicobar Islands (17, June, 2017).

\section{MATERIAL AND METHODS}

\subsection{STUDY AREA}

Nandurbar district is the North West corner of Maharashtra State of India. On 1 June 1998, Dhule district was bifurcated and Nandurbar district is formed. It have $5035 \mathrm{~km}^{2}$ area. It is bounded to South and South East by Dhule district. To the West and North is the state Gujarat, To the North and North East is the Madhya Pradesh. Northern boundary is defined by Narmada River.

By taking databases from Primary Health Centres (PHC), reports (from2004-2005), Malaria officer, as well as District Health Officers collected in December in Navapur Tahsil as well as Rural areas during 14-16 December (2015). Globally, 120 million people are infected by Filariasis, in India more than 5000 people are infected with Filariasis every year. Causing more economic losses to people of globe.

\section{DISCUSSION}

As the Navapur Tahsil is disease prone zone of elephantiasis. District Health Officers (DHO) of Navapur and Nandurbar District organised a campaign for prevention of elephantiasis. They distributed the medicines to the people of Navapur Tahsil. Because in Nandurbar District 26 cases were found positive. And 118 (-ve) cases were record with results in check up. In Navapur Tahsil 13 patients are noticed by (DHO). For prevention of elephantiasis different drugs were given to people in Navapur Tahsil whole Nandurbar District.,like albendazole and DEC(DiEthylCarbamazine) tablets. These tablets prevent elephantiasis if people suffering from elephantiasis and transmitter of elephantiasis take this regularly. Therefore, each and every suffering from elephantiasis.

\section{TREND AND PRESENT SCENARIO}

In India, it is estimated to be over 250 district, and 20 States putting 650 million people at risk. In India, 99.4\% cases caused by the W. bancrofi and $0.6 \%$ by B. malayi (17, Nov. 2017). About 5 crore people in India and $40 \%$ people in globe carrying infections. Treatment is given to 40 crore people in India. Dr. Harshavardhan, told 2021 is eradication year for lymphatic Filariasis. States of Bihar over 17\%, Kerala 15.7\%, U. P. 14.6\%, T. N. 10\%, Assam 5\%, M. P. 3\%, and Goa less than 1\%, lymphatic Filariasis.

Such out break also occur in Andhrapradesh, 25/5/2020, Chief Minister of the A. P., Y.S.Jagan Mohan Reddy, discussed the situation and people are provided with proper medical care facility. 
In India, such recently available record, but WHO, decided to control and eradicate Filariasis upto year, 2020. In 2015, about 38.5 million people were infected, about 950 million people were at the risk of Filariasis in 54 countries. It is the most common in tropical Africa and Asia. It causes economic losses of billions of dollars per year.

In 2015, WilliamC. Campbell and Santoshi Omura awarded Nobel Prize for drug in Filariasis in Physiology/Medicine drug ivemectia.

\section{CARE OF ELEPHANTIASIS PATIENTS}

Patients are given instructions that, Albendazole and DEC tablets prevents elephantiasis.

1) But these tables should be taken only one time at noon or night after dinner.

2) From DHO chemical or drugs are given to PHC hospitals.

3) Trainings are given to people as well as campaigns are arranged in school and colleges regarding prevention of elephantiasis in Navapur Tahsil during December and January (2015-2016).

4) Meetings were held and information was given to people about elephantiasis.

According to a New technology for treatment was recently developed in United States.

A Genomic Research University of Maryland (December, 5,2019), Using innovative RNA sequencing technique, lymphatic Filariasis, a disabling parasitic disease that, therapy is an experimental cancer drug called JQ1 and target proteins found prominently in the worm's genome and kills the adult worms in a laboratory setting. According to study, a tropical parasitic disease that affects the lymph nodes and lymph vessels. As lymphatic Filariasis is a leading cause of permanent disability globally. According to the Centers for Disease Control and Prevention (5, December,2019).

"The drug JQ1 works by inhibiting bromodomain containing proteins that are necessary for the adult worms to live “, Said Study Author Julie Dunning Hotopp, Ph. D., Professor of Microbiology and Immunology, Institute of Genome Sciences, University of Maryland, School of Medicine, Novel Therapeutic leads to Lymphatic Filariasis Guided by Multispecies Transcriptomics. mSystems DOI.

\section{NECESSARY ACTIONS}

1) People should be made prepared for fighting against Filariasis.

2) Schools and Colleges must be prepared for awareness among the Filariasis and other insect borne and other diseases.

3) People must be aware of their own personal cleanliness and better living practices. It will prevent to growth of Mosquito and other insects.

4) People must be educated with spraying oil/ kerosene over ditches around surrounded dirty areas for preventing growth of weeds.

5) Use house clean and window and doors screening should be done for prevention of mosquito bite.

6) Various awareness programme about different disaster/ calamities of diseases should be avoided by showing Audio-visuals to the people who are illiterate.

7) Use of mosquito- nets against the disease/mosquito bite.

8) Tablets were given to the patients from curing different epidemic and endemic diseases.

9) People survey for different season episode of different disease outbreak.

10) It is very useful for avoiding spread of disease.

11) Awareness Campaign are held for prevention and Control of the disease.

12) Meetings and Social worker, Health Worker information helps the people to cure diseases.

\section{OBSERVATION AND RESULTS}

Tahsil of Nandirbar district and the Number of elephantiasis patients positive (+ve), and negative. (-ve) are shown in the following table as below:-

\begin{tabular}{|c|c|c|}
\hline Name of Tahsil & Patients(+ve) & Patients(-ve) \\
\hline Shahada & $01+$ & Nil - Ve 00 \\
\hline
\end{tabular}




\begin{tabular}{|c|c|c|}
\hline Taloda & $05+v e$ & $29-$ Ve 00 \\
\hline Navapur & $13+v e$ & $78-$ Ve 00 \\
\hline Nandurbar & $03+v e$ & $07-\mathrm{Ve}$ \\
\hline Dhadgaon & $04+v e$ & $00-\mathrm{Ve}$ \\
\hline Akkalkuwa & $00+\mathrm{ve}$ & $04-\mathrm{Ve}$ \\
\hline Total & $\mathbf{2 6}+\mathbf{v e}$ & $\mathbf{1 1 8}-\mathbf{V e}$ \\
\hline
\end{tabular}

\section{CONCLUSION}

1)Culex pipiens, $C$. fatigans, C. quinquefaciatus are endemic species are one enemies of man causing elephantiasis disease so its control is very essential. India, contributes $41 \%$ of global lymphatic Filariasis. (1997). So it is very important to control this disease. 2.) Awareness among the people, among, society, in Schools, Colleges levels should be done for eradication of Filariasis disease from various parts of globe.

\section{SOURCES OF FUNDING}

None.

\section{CONFLICT OF INTEREST}

None.

\section{ACKNOWLEDGMENT}

I am very much thankful to my Management of S.S.V.P. S’s L. K. Dr. P. R. Ghogrey Science College, Dhule, for giving me help time to time.

\section{REFERENCES}

[1] Agrawal, V. K. \&V.K.Shashidran , (21, June, 2011) :- Lymphatic Filariasis in India, Problems, Challenges, \&New initiatives. Medical Journal of Armed Forces India.

[2] Ahirrao, I. S. (1996-2009) -Taxonomic Studies on some insect Orders viz., Diptera, Lepidoptera and Coleoptera of Dhule district. Ph. D. Thesis submitted to KBCNMU, JALGAON, India.

[3] Lokmat Daily Newspaper, Published data (2015, December, 15-16).

[4] Multispecies Transcriptomics. mSystemsDOI:-http://doi.org/10.1128/mSystems 00596-19.

[5] Center for Disease Control and Prevention. "Lymphatic Filariasis". Retrieved,18 July,2010.

[6] "Lymphatic Filariasis, ". Health tropics, A to Z sources, The WHO,, Retrieved 24,Mar.2013.

[7] Wheeler, L. "Microfilarae of Dirofilaria immitis (Heart worms) surrounded by the Non-plastic Lymphocytes".Flickr.Retrieved 2,Dec.2017.

[8] "Seva Fila "(PDF):-JB.Tropical Diseases Research Centre and Department of Biochemistry, Mahatma Gandhi Institute of Medical Sciences.

[9] United States Centres for Disease Control,Lymphatic Filariasis, treatment, Retrieved, 17,July, 2008.

[10] Taylor, M. J. (October, 2010): -Lymphatic Filariasis, Lancet 376. (9747) :1175-85, doing:10.

[11] Basu, B. C. \&Rao, S. S. (1939) Ind. Journal of Medical Research, 27,233.

[12] Elephantiasis (2009): -https://rare diseases. Org/rare diseases/elephantiasis.

[13] Chandler A. (1924-1929) :-Parasitology, 16,398.

[14] Bhalerao, G. D. (1935) Imperial Council of Agriculture and Research. Monograph, 6.

[15] Chatterjee, K. C. (1954) Indian Journal of Medical Association, 24,146.

[16] Frequently Asked Questions (FAQS) (June 15,2014): -https://www.cdc.gov/parasites/lymphatic filariasis/gen.info/faqs.html

[17] N. G. S. Raghavan, (1957) :-Epidemiology of Filariasis in India. 16,553-579. 
[18] Hoerauf, A. (2008) December, Filariasis New drugs and new opportunities for lymphatic Filariasis and Onchocerciasis: - Current opinion in infectious diseases 21, (6) 673-681.

[19] Ganguly, N. K. (9, Jan. 2018) :- The final lap towards elimination of lymphatic Filariasis. Business Line.

[20] Senthilingam, Meera, (24, April 2015) :-Every last Worm : Eliminating Elephantiasis in India. CNN.

[21] Sharma, Neetu Chandra (30 October, 2019)- India to eliminate lymphatic Filariasis by 2021:-Dr. Harshvardhan , Minister of Government of India, Livemint.

[22] Kuttial, et. al. (January 2020):-Frequent \&clinical significance of Localized Adverse Events following Mass Drug Administration (MDA) for Lymphatic Filariasis in endemic Areas of South India:-The American Journal of Tropical Medicine And Hygiene. :-102(1) :96-99 doi: 10.4269/ajtmh. 19-0532.

[23] Roshan K. Padvi, Study of common mosquitoes species in Toranmal Hill Station Circle of Nandurbar district. (January 20,2019) https://www.researchgate.net ISSN: -2455-2631, IJRDS Vol. (4) . Issue 1. 